\title{
Фонд С. М. Шапшала в Библиотеке Врублевских Литовской академии наук ${ }^{1}$
}

\author{
Александр Азарьевич Бабаджан \\ Религиозная объединённая община «Чолпан»
}

\begin{abstract}
The Seraya Shapshal Collection at the Wroblewski Library of the Lithuanian Academy of Sciences
\end{abstract}

\begin{abstract}
Summary: The article describes the structure and some of the materials from the Seraia Shapshal collection at the Wroblewski Library of the Lithuanian Academy of Sciences. The author analyses the content of all seven sections of the collection - the collection mostly contains materials from the time when Shapshal was resident in Poland and Lithuania (1928-1961). However, we can also find here - although to a lesser degree - materials from his student days (1898-1899), from his years in Persia (1900-1908), and from the 1908-1919 period, as well as from his stay in Turkey (1920-1928). The material examined in the article provides some insights into the life of S. Shapshal and allows us to verify some facts from his biography.
\end{abstract}

Keywords: Seraya Shapshal collection, Karaims, turkology

Библиотека Врублевских Академии наук Литвы, одна из крупнейших в стране - это публичная научная библиотека Литвы государственного значения. Она основана в 1941 году на базе библиотек евангелико-реформатского синода (основанной в 1557 году) и Государственной

\footnotetext{
1 Статья написана на основе изучения автором материалов фонда С. Шапшала в 1996-2013 гг.
} 
публичной библиотеки Эустахия и Эмилии Врублевских (основанной в 1925 году адвокатом Тадеушем Врублевским) как Центральная библиотека Академии наук Литовской ССР. После Второй мировой войны фонды библиотеки пополнились изданиями и рукописями библиотек закрытых костёлов и монастырей, национализированных музеев, обществ, поместий, а также частных библиотек Коссаковских, Тышкевичей, Рёмеров.

Именно в эту библиотеку и были сданы все материалы, которые находились в доме Сераи Марковича Шапшала после его кончины. Первичной подготовкой и группировкой материалов занимался Ромуальд Фиркович (это теперь он - самый крупный специалист по архивам Литвы, и ни одно крупное издание по материалам архивов не обходится без его участия, а тогда его работу по упорядочению материалов переделали и сделали хуже). Например: фотографии с С. Шапшалом есть в 1 и 5 разделах, поздравления С. Шапшалу разбросаны по трем разделам - 1, 2, 4, а переписку можно найти не только во 2 основном разделе, но и в 3, и в 4, и т.д.

Всю картотеку записали на литовском языке, что сильно затрудняет работу с фондом С. Шапшала F-143. Фонд содержит около 1650 дел. Материал разделен на 7 больших разделов, часть из которых разделена на подразделы. Дела могут содержать от одного документа до толстых папок по 200-30о листов, но есть три особых дела, в которых более 2500 карточек. Основной язык материалов - русский, но много материалов на польском, караимском, литовском, персидском, турецком, немецком, английском, арабском, гебрайском, итальянском, французском. Большая часть материалов относится к периоду пребывания С. Шапшала в Литве, т.е. с 1928 по 1961 гг., но есть материалы студенческих лет, например, работа 4 курса 1898-1899 годов. Есть материалы персидского периода 1900-1908 гг., времени более позднего проживания в России 1908-1919 гг., турецкого периода 1920-1928 гг. Все эти материалы всесторонне освещают как научную и общественную деятельность С. Шапшала, так и его личную жизнь.

Первый раздел - персоналия, куда входят дела с 1 по 115. В этом разделе находятся различные паспорта С. Шапшала - царской России, польский, литовский, советский, паспорта для заграничных поездок, разные удостоверения, профсоюзные билеты, пенсионное удостоверение, дипломы, автобиографии, документы жены и ее брата - художника Барри Эгиза, финансовые документы из Персии, Турции, Польши, 
Литвы и СССР. Сюда же включены записные книжки, тетради С. Шапшала по обучению польскому и литовскому языку, часть письменных поздравлений, переписки и фотографий.

Второй раздел - корреспонденция, в него входят дела с 116 по 803. Этот раздел поделен на несколько подразделов. Первый - письма С. Шапшала, куда входят дела с 116 по 154. Здесь находятся сохранившиеся черновики и копии писем, которые С. Шапшал посылал по разным поводам. Например, письмо проф. Т. Ковальскому, письмо по поводу организации экспедиции К. Джини и к самому К. Джини, письма по поводу статей о караимах, о хазарском языке, некоторым людям, например, Т. Леви-Бобовичу, А. Мардковичу, И. Я. Нейману, здесь же находятся тексты двух писем, посланных 1.12.1948 и 23.02.1950 И. Сталину, частные письма С. Шапшала.

Второй подраздел содержит письма, присланные С. Шапшалу. Это дела 156-738. Здесь содержатся письма по поводу научной деятельности, например, письма проф. А.Башмакова, проф. Т.Ковальского, проф. Н. Баскакова, этнографа Г. Федорова, акад. А. Зайончковского, газзанов Р. Абковича и И. Абрахамовича, С. Сарача, С. Кальф-Калифа и многих других, корреспонденция к С. Шапшалу, как к главе караимов, поздравительные и благодарственные письма и открытки, письма с просьбами о помощи, личная переписка С. Шапшала.

В третьем подразделе (дела 739-783) содержатся письма неизвестных авторов к С. Шапшалу, а в четвертом - корреспонденция его жены Веры Эгиз (дела 785-803).

В третьем разделе (805-929) находятся научные работы С. Шапшала. Это три дела, два из которых (около 2800 и одно - более 3700 листов) составляют картотеки караимских слов, послужившие основой караимско-русско-польского словаря, изданного после смерти С. Шапшала. Здесь находятся как окончательные варианты научных работ и книг, опубликованных и не опубликованных, так и различные их варианты разного времени. Например, три варианта по истории караимов, датируемые, первый $-193{ }_{-}^{2}-1942$ годами, второй -1949 г. и окончательный вариант «История тюрков-караимов в Крыму, Литве и Польше» — 195_. Здесь же хранятся рукописи работ С. Шапшала: «Этническая

2 В тех случаях, когда на документах нет даты, и специалисты смогли датировать документ с точностью до 10 лет, стоит дата, например, (193_). Но есть и такая датировка материала - (19 
принадлежность караимов» (1951), «Караимы и их язык» (1952), «К вопросу об этногенезе караимов» (1957), «Об исторической связи Литвы с тюркскими странами и народами», «Значение г. Вильнюса в отношении вопросов востоковедения» (1951), «Научный обзор предметов материальной культуры, хранящихся в караимском отделе ИсторикоЭтнографического музея» (195_), «9о слов в усилительно-превосходной степени» (19__), «Приключения Гахана Хаджи Ага Бабовича» (193_), «Hachan Romuald Kobecki» (1936), «Краткий обзор нынешнего состояния религиозных дел у караимов» (1946-1947), «Образцы народного творчества азербайджанцев Персии», «Примеры народной литературы турков Персидского Азербайджана» (1934-1935), «Изображения мусульманских Святых и влияние католической иконографии в Персии и персидско-польские отношения при Сигизмунде III» (1934), «О языке гуннов», «Хазары и их язык» (1957), «Валентин Алексеевич Жуковский. (Воспоминания ученика)» (195_), «Baszkirowie» (194_-195_), «Крымские готы» (195_), статьи для журналов «Мысль Караимская» и «Rocznik Tatarski» (1929-1932) статьи о спичечных коробках, о тюркских монетах, о тарханных ярлыках и многое другое. Много дел с черновыми набросками, заметками, выписками из разных источников, караимские молитвы, псалмы, караимские литургические тексты. Сюда же помещены образцы печатей газзанов и печати Гахана Польши, несколько рецензий на работы С. Шапшала, переписка о статьях, тексты речей, словарик турецкого языка для высшей школы научно-исследовательского института Восточной Европы 1932 года.

Четвертый раздел содержит материалы, относящиеся к работе С. Шапшала, не связанной с научной работой. Он разбит на четыре подраздела. Первый подраздел, дела 923а-943, содержит материалы, связанные с работой С. Шапшала в Персии и Константинополе. По персидскому периоду только четыре дела, в которых находится отзыв неизвестного автора о шахе Музафаре-ед-дине и его наследнике, уроки персидского принца и корреспонденция Шапшала в Персии на французском, русском и персидском языках, датируемая 1905-1908 годами. К турецкому периоду относятся документы Турецко-персидского банка - документы, чеки, контракты, договора и т.д. на турецком, французском, русском.

Второй подраздел, дела 944-968, содержит материалы, связанные с деятельностью тюркологического кружка и ориенталистического общества. 
Третий подраздел, дела 969-1091, содержит материалы, связанные с деятельностью Тракайского караимского правления, начиная с 1919 года по 1944 год, хотя попадаются материалы и более позднего периода. Здесь помещается обширная международная переписка с лицами, обращавшимися с просьбой о предоставлении свидетельств их караимского происхождения, много поздравлений Гахану, тексты речей, финансовые документы, в том числе религиозных общин, храмов, «Kiorklu Sala» (Малеванки), журнала «Myśl Karaimska», материалы об оказании помощи в строительстве мечети в Варшаве, свидетельства, справки. Есть материалы по выборам С. Шапшала Гахамом и по его переезду в Вильнюс, караимские календари за разные годы, грамоты о награждении С. Шапшала польским орденом и сопроводительные письма о статусе этого ордена и др.

Четвертый подраздел - дела 1092-1136, связанные с караимским музеем. Здесь находится устав и опись экспонатов музея 1938 г., акт инвентаризации музея 1946 г. и акты о передаче 1961-1962 гг.

Пятый раздел - коллекция, дела 1137-1342. В ней представлены печатные издания, книги, карты, фотографии, открытки, акварельне рисунки. Здесь есть книга А. Фирковича «Сефер Авнэ Зикарон» (1872) с пометками С. Шапшала, работа Я. Гжегожевского 1903 года, Устав общества помощи караимам, пострадавшим от военных действий 1915 года, много вырезок из газет, журналы, работы А. Башмакова, статья о А. Фуки. Много фотографий литовских, галицких, луцких, крымских, парижских караимов, караимских мест, отдельных караимов, есть большие изображения А. Фирковича, С. Пампулова. Есть снимки Николая II, снимки караимских орнаментов, тканей, вышивок, есть даже выкройка караимского костюма, а также хранятся 4 фирмана.

Шестой раздел - дела 1343-1601. Подразделами выделены материалы В.Котвичюса, дела 1343-1450, и И. Лобаноса, дела 1451-1460, где хранятся переводы “Одиссеи”, стихов Хафиза, поэмы “Саша” I-II части и других авторов на караимский язык.

В третьем подразделе, дела1461-1601, хранятся напечатанные работы караимов по караимской тематике. Например, три работы М. Ф. Бабаджана по этногенезу, истории и архитектуре караимов, статьи Б. С. Ельяшевича о И. И. Казасе, И. С. Бабаджане, Д. Б. Паше, И. С. Ельяшевиче, две статьи С. А. Фирковича и его переводы выдержек из книги Э. Дейнарда, две работы Б. Кокеная, караимские легенды, собранные А. Шишманом, стихи С. Кобецкого, элегии М. Казаса, статья 
Т. С. Леви-Бобовича «Египетские караимы» (1935), статья А. Шишмана о Б. И. Эгизе (1945). Кроме того, работы А. Башмакова и полный перевод его монографии на русский, статья Г. Кирринниса 1943 г. о караимах, ответ Г. Дебица о караимах, письмо С. Познанского 1938 г. и многое другое.

Седьмой раздел, дела 1602-1630, содержит различное, не вошедшее в предыдущие разделы.

На основании изучения материалов этого фонда можно сделать некоторые уточнения деталей жизни С. Шапшала:

1. Научным руководителем С. Шапшала был проф. Н.И.Веселовский.

2. Курсовая работа студента 4 курса С. Шапшала отличается от изданной брошюры о Джуфт Кале. Она дополнена анализом статьи «Исторические очерки караимства» А. Гаркави, опубликованной в журнале «Восход» в 1897 г.

3. В 1899 г. с 4 июня начинается поездка С. Шапшала в Париж, где он в июле и августе работает в библиотеке над материалами.

4. С 1901 г. по 1917 г. С. Шапшал работал в Министерстве Иностранных Дел России.

5. В Персии Шапшал не был замешан в расстреле меджлиса и о нем в Персии сохранилось хорошее мнение.

6. Сватовство шахом Веры Эгиз произошло в 1909 г. в Одессе, где она вышла замуж за С. Шапшала.

7. В августе 1919 г. был в Константинополе.

8. Вещи С. Шапшала в Константинополь были вывезены без спешки, с большим архивом, скорее всего женой.

9. Уточнена дата решения караимского вопроса в Германии постановление министерства внутренних дел от 22 декабря 1938 г.

10. С. Шапшал неоднократно дарил экспонаты разным музеям, в том числе и еврейскому музею, собрав и сохранив предметы еврейской культуры во время войны. 